\title{
ANALISIS SIKLUS KEBIJAKAN SEKOLAH RAMAH ANAK DI MTSN 6 SLEMAN
}

\author{
Diah Rusmala Dewi \\ Universitas Islam Negeri Sunan Kalijaga Yogyakarta \\ diahrd95@gmail.com
}

\begin{abstract}
This study aims to describe the cycle of child-friendly school policies in MTsN 6 Sleman. This type of research is descriptive qualitative. Data collection techniques using interviews, observation and documentation. Source triangulation is carried out to obtain data validity. Data analysis techniques include data collection, data reduction, data presentation, and verification or conclusion drawing. The results of the study include: the child-friendly school policy cycle in MTsN 6 Sleman including after passing through the stages of agenda preparation, policy formulation, and policy adoption, four policy packages were born to strengthen the Child Friendly School Policy (SRA) so that it can be implemented in the regions, one of which is at MTsN 6 Sleman involving all parties involved. The results of the study include: the child-friendly school policy cycle in MTsN 6 Sleman including after passing through the stages of agenda preparation, policy formulation, and policy adoption, four policy packages were born to strengthen the Child Friendly School Policy (SRA) so that it can be implemented in the regions, one of which is at MTsN 6 Sleman involving all parties involved. Then, the stages of implementing child-friendly school policies in MTsN 6 Sleman, namely: Bureaucratic Structure, Communication of Human Resources, infrastructure, and finance, and Disposition. The learning model used in MTsN 6 Sleman is sufficient to apply the principles of child-friendly schools, namely provision, protection, and participation. Supporting factors are human resources, infrastructure, and financial while the inbibiting factor is the lack of maximum infrastructure and financial resources in creating facilities that are friendly for children with disabilities. Monitoring and evaluation of the implementation of friendly school programs in MTsN 6 Sleman is carried out by the SRA Development Team and involves the KLA task force and other agencies.
\end{abstract}

Keywords: Policy Cycle, Child Friendly Schools, MTsN 6 Sleman.

\begin{abstract}
Abstrak : Penelitian ini bertujuan untuk mendeskripsikan siklus kebijakan sekolah ramah anak di MTsN 6 Sleman. Jenis penelitian ini adalah deskriptif kualitatif. Teknik pengumpulan data menggunakan wawancara, observasi dan dokumentasi. Dilakukan triangulasi sumber untuk mendapatkan keabsahan data. Teknik analisis data meliputi pengumpulan data, reduksi data, penyajian data, dan verifikasi atau penarikan kesimpulan. Hasil penelitian meliputi: siklus kebijakan sekolah ramah anak di MTsN 6 Sleman diantaranya yaitu setelah melalui tahapan penyusunan agenda, formulasi kebijakan, dan adopsi kebijakan, lahirlah empat paket kebijakan untuk memperkuat Kebijakan Sekolah Ramah Anak (SRA) agar dapat terimplementasi di daerah, salah satunya yaitu di MTsN 6 Sleman dengan melibatkan partisipasi semua pihak. Kemudian, tahap implementasi kebijakan sekolah ramah anak di MTsN 6 Sleman yaitu: Struktur Birokrasi, Komunikasi Sumber daya manusia, sarana prasarana, dan finansial, serta Disposisi. Model pembelajaran yang digunakan di MTsN 6 Sleman sudah cukup menerapkan prinsip sekolah ramah anak yaitu provisi, proteksi, dan
\end{abstract}

Manazhim : Jurnal Manajemen dan Ilmu Pendidikan

Volume 2, Nomor 1, Februari 2020; 1-18

https://ejournal.stitpn.ac.id/index.php/manazhim 
partisipasi. Faktor pendukungnya yaitu sumberdaya manusia, sarana prasana, dan finansial sedangkan faktor penghambatnya adalah kurang maksimalnya sumberdaya sarana prasarana dan finansial dalam mewujudkan fasilitas yang ramah bagi anak berkebutuhan khusus. Monitoring dan evaluasi implementasi program sekolah ramah di MTsN 6 Sleman dilakukan oleh Tim Pengembangan SRA dan melibatkan gugus tugas KLA dan Dinas atau lembaga lainnya.

Kata Kunci : Siklus Kebijakan, Sekolah Ramah Anak, MTsN 6 Sleman

\section{PENDAHULUAN}

Seiring dengan perubahan dan perkembangan zaman, masalah yang dihadapi pun kian kompleks juga memunculkan masalah-masalah pendidikan pada berbagai levelnya. Di dunia pendidikan, budaya kekerasan, ujaran kebencian, dan kemerosotan akhlak yang lainnya cukup terasa belakangan ini bahkan dapat dengan mudah kita temui dalam kehidupan sehari-hari di sekitar kita saat ini. Selain itu, muncul pula keresahan orang tua dan masyarakat akan banyaknya kasus-kasus kekerasan, masih adanya anak yang merasakan bahwa bersekolah bukan menjadi sesuatu yang menyenangkan, kasus anak yang menjadi korban karena sarana prasarana yang tidak kokoh, sarana prasarana yang standarnya belum terpenuhi, kehujanan, kebanjiran, bahkan kelaparan, selain ancaman mengalami bullying dan kekerasan yang dilakukan oleh guru maupun teman sebaya, juga kasus keracunan pada anak karena jajanan yang tercemar zat-zat berbahaya masih menjadi sesuatu yang belum dapat dihindarkan terjadi di sekolah.

Berdasarkan data yang bersumber dari Komisi Perlindungan Anak Indonesia (KPAI), kasus kekerasan terhadap anak semakin meningkat setiap tahunnya. KPAI memamaparkan bahwa perundungan berupa kekerasan fisik, psikis, dan seksual masih mendominasi pelanggaran hak anak di bidang pendidikan. Selain itu, berdasarkan pelaporan yang diterima oleh KPAI, korban kekerasan psikis dan bullying masih tertinggi. Adapun di posisi kedua yaitu kasus anak korban kebijakan dan kekerasan fisik meliputi pemberian sanksi yang mempermalukan kepada anak, termasuk memberikan sanksi yang keras setelah anak melakukan kesalahan atau pelanggaran, sementara kasus terendah yaitu korban pengeroyokan dan kekerasan seksual. Dengan rincian per Januari sampai dengan April 2019 yaitu anak korban kebijakan sebanyak 8 orang, pengeroyokan sebanyak 3 kasus, korban kekerasan 
seksual sebanyak 3 kasus, kekerasan fisik sebanyak 8 kasus, serta anak korban kekerasan psikis dan bullying sebanyak 12 kasus dan anak pelaku bullying terhadap guru sebanyak 4 kasus. ${ }^{1}$

Berdasarkan jenjang pendidikan pada Januari hingga April 2019, mayoritas kasus terjadi di jenjang pendidikan Sekolah Dasar (SD) yaitu sebanyak 37 kasus kekerasan dengan rincian 25 kasus atau mencapai 67 persen terjadi di SD, jenjang SMP sebanyak 5 kasus, SMA sebanyak 6 kasus, dan Perguruan Tinggi sebanyak 1 kasus. ${ }^{2}$ Besarnya angka kekerasan terhadap anak yang bahkan terjadi dalam dunia pendidikan sangat memprihatinkan. Lembaga pendidikan yang semestinya menjadi tempat yang aman untuk anak-anak ternyata juga belum mampu memberikan jaminan terbebasnya anak dari kekerasan.

Salah satu perwujudan dari konsep pendidikan untuk semua (education for all) atau yang biasa disebut dengan Pendidikan Dasar telah menjadi isu kebijakan penting bagi setiap negara di dunia. Pendidikan untuk semua adalah konsep universal pengembangan SDM yang menaruh perhatian pada pogram pendidikan bagi semua segmen masyarakat. Bagian penting dari pendidikan untuk semua adalah pendidikan dasar yang diarahkan pada penanaman kemampuan dasar minimum yang harus dimiliki oleh semua warga negara. ${ }^{3}$

Untuk itulah, diperlukan kesadaran dan perencanaan terutama dalam mewujudkan suasana dan proses pembelajaran yang efektif dan efisien sehingga peserta didik dapat mengembangkan potensi dirinya secara aktif yang nantinya diharapkan terbentuk kekuatan spiritual keagamaan yang tinggi, kecerdasan, pengendalian diri, kepribadian, akhlak mulia serta keterampilan dalam dirinya yang akan berguna baik bagi dirinya, masyarakat, bangsa dan negara.

Tentunya, upaya pencapaian proses belajar tersebut haruslah mendapat dukungan dari semua pihak, termasuk dari Kementerian Pemberdayaan Perempuan dan Perlindungan Anak sebagai salah satu Kementerian yang memiliki peran dalam

\footnotetext{
${ }^{1}$ https:// news.detik.com/berita/d-4532984/kpai-angka-kekerasan-pada-anak-januari-april2019-masih-tinggi, diakses pada tanggal 19 November 2019, pukul 15.10 WIB.

2 https:// news.detik.com/berita/d-4532984/kpai-angka-kekerasan-pada-anak-januari-april2019-masih-tinggi, diakses pada tanggal 19 Novemver 2019, pukul 15.10 WIB.

3 M. Hasbullah, Kebijakan Pendidikan: Dalam Perspektif Teori, Aplikasi, dan Kondisi Objektif Pendidikan di Indonesia, (Jakarta: Rajawali Pers, 2015), hal. 155.
} 
perlindungan anak dimana dapat mendorong pemerintah pusat, provinsi dan kabupaten atau kota dalam mewujudkan apa yang disebut dengan Sekolah Ramah Anak (SRA) yaitu suatu kondisi sekolah atau lingkungan pendidikan yang aman, nyaman, sehat, ramah dan menyenangkan bagi anak serta terpenuhi haknya. Hal ini sudah seharusnya menjadi perhatian penting, mengingat sekolah menjadi tempat anak menghabiskan sebagian besar waktunya sehingga menjaga dan melindungi anak selama waktu tersebut seharusnya menjadi hal yang prioritas dan dilakukan bersamasama oleh semua unsur yang ada di sekolah mulai dari Kepala Sekolah, Guru, Guru BK, penjaga Sekolah dll, bahkan sangat perlu adanya kerjasama yang baik dan terarah antara sekolah dengan orang tua, lembaga masyarakat, berbagai instansi maupun alumni untuk mendukungnya.

Salah satu sekolah Islam yang menerapkan kebijakan Sekolah Ramah Anak (SRA) adalah MtsN 6 Sleman. MTsN 6 Sleman merupakan salah satu sekolah yang selama ini dijadikan sebagai tempat studi banding madrasah-madrasah lain baik di sekitarnya maupun dari luar daerah, dimana setiap bulan selalu ada agenda kunjungan dari berbagai MTs lain. Selain itu, baru-baru ini kepala sekolah MTsN 6 Sleman bersama 4 kepala sekolah madrasah lainnya mendapatkan nominasi penganugerahan kepala sekolah madrasah terbaik se Indonesia. Berdasarkan hal tersebut, peneliti tertarik untuk melakukan penelitian terkait penerapan Kebijakan Sekolah Ramah Anak di MTsN 6 Yogyakarta.

\section{KAJIAN PUSTAKA}

A. Konsep Dasar Siklus Kebijakan

Kebijakan pendidikan (educational policy) merupakan penggabungan dari kata education dan policy. Kebijakan adalah seperangkat aturannya, sedangkan pendidikan menunjukkan pada bidangnya. Dengan demikian kebijakan pendidikan merupakan kebijkan publik dalam bidang pendidikan. ${ }^{4}$

Siklus pembuatan kebijakan publik merupakan proses yang kompleks karena melibatkan banyak proses maupun variabel yang harus dikaji. Kebijakan

4 A. Rusdiana, Kebijakan Pendidikan Dari Filosofi Ke Implementasi, (Bandung: Pustaka Setia, 2015), hal. 37. 
publik dibuat oleh beberapa aktor atau pejabat antara lain yaitu legislatif, eksekutif, intansi administrasif dan lembaga peradilan. Sedangkan, untuk yang non pemerintah ada kelompok kepentingan, partai politik, dan warga negara. Untuk memudahkan dalam mengkaji siklus kebijakan publik, proses pembutatan kebijakan publik dibagi menjadi beberapa tahapan, diantaranya yaitu: ${ }^{5}$

1 Tahap penyusunan agenda

Masalah untuk sampai pada agenda publik haruslah melalui seleksi dari pejabat terpilih. Pada tahap ini, terdapat kemungkinan suatu masalah tidak disentuh sama sekali, sementara masalah yang lain ditetapkan menjadi fokus pembahasan, atau karena alasan-alasan tertentu ada pula masalah menjadi ditunda untuk waktu yang lama.

2. Tahap formulasi kebijakan

Para pembuat kebijakan kemudian membahas untuk mencari pemecahan terbaik atas masalah yang telah masuk ke agenda kebijakan. Pemecahan masalah tersebut berasal dari berbagai alternatif atau pilihan kebijakan yang ada. Pada tahap ini, masing-masing aktor akan "bermain" untuk mengusulkan pemecahan masalah terbaik.

3. Tahap adopsi kebijakan

Pada akhirnya, salah satu dari sekian banyak alternatif kebijakan yang ditawarkan oleh para perumus kebijakan tersebut diadopsi dengan dukungan dari mayoritas legislatif, konsensus antara direktur lembaga atau keputusan peradilan.

4. Tahap implementasi kebijakan

Jika suatu program yang telah ditetapkan kemudian tidak diimplementaiskan, hal tersebut hanya akan menjadi catatan-catatan elite yang tidak ada artinya. Oleh karena itu, badan-badan administrasi maupun agenagen pemerintah ditingkat bawah menjadi bagian yang mengimplementasikan

${ }^{5}$ Budi Winarno, Kebijakan Publik: Teori, Proses, dan Studi kasus, Yogyakarta: CAPS (Center of Academic Publishing Service), 2014), hal. 35-37. 
keputusan program kebijakan yang telah dipilih sebagai alternatif pemecahan masalah.

\section{Tahap evaluasi kebijakan}

Untuk melihat sejauh mana kebijakan yang dibuat telah mampu memecahkan masalah, diperlukan penilaian atau evaluasi terkait kebijakan yang telah dijalankan. Oleh karena itu, ditentukanlah ukuran-ukuran atau kriteria-kriteria yang menjadi dasar untuk menilai apakah kebijakan publik telah meraih dampak yang diinginkan.

B. Aspek-aspek yang Mempengaruhi Pelaksanaan Kebijakan Publik

Pelaksanaan kebijakan menurut George C. Edwards III adalah bagian dari tahapan proses kebijakan yang posisinya berada diantara tahapan penyusunan kebijaksanan dan konsekuensi-konsekuensi yang dimunculkan oleh kebijaksanaan tersebut (output, outcome). Lebih lanjut, hasil identifikasi Edwards III pada aspekaspek yang dianggap berkontribusi kuat dalam implementasi kebijakan, yaitu: struktur birokrasi, komunikasi, sumberdaya dan disposisi atau sikap pelaksana. Baik secara langsung maupun tidak langsung, keempat aspek tersebut mempengaruhi pelaksanaan kebijakan dan masing-masing aspek saling berpengaruh terhadap aspek lainnya. ${ }^{6}$

1. Kewenangan/Struktur Birokrasi.

Otoritas atau legitimasi bagi para pelaksana dalam melaksanakan kebijakan yang ditetapkan secara politik atau yang biasa disebut juga dengan kewenangan berkaitan dengan struktur birokrasi yang melekat pada posisi atau strata kelembagaan atau individu sebagai pelaksana kebijakan. Karakteristik utama dari birokrasi umumnya tertuang dalam prosedur kerja atau Standard Operating Procedures (SOP) dan fragmentasi organisasi. ${ }^{7}$

2. Komunikasi.

Aktivitas yang mengakibatkan orang lain menginterprestasikan suatu ide atau gagasan terutama yang dimaksudkan oleh pembicara atau penulis

\footnotetext{
${ }^{6}$ Abdullah Ramadhani, Muhammad Ali Ramadhani, "Konsep Umum Pelaksanaan Kebijakan Publik", Jurnal Publik, Vol. 11 No. 01, Januari 2017, hal. 5.

${ }^{7}$ Ibid., hal. 5 .
} 
melalui sesuatu sistem yang biasa atau lazim baik dengan simbol-simbol, signal-signal, maupun perilaku, biasa disebut juga sebagai pengertian dari komunikasi. Komunikasi menjadi yang turut serta dalam mempengaruhi pelaksanaan kebijakan publik, dimana komunikasi yang tidak baik dapat menimbulkan dampak-dampak buruk bagi pelaksanaan kebijakan.

Transmisi, konsistensi, dan kejelasan menjadi dimensi komunikasi yang dapat mempengaruhi pelaksanaan kebijakan publik. Syarat-syarat dalam pencapaian keberhasilan pelaksanaan kebijakan publik diantaranya yaitu pemahaman unsur pelaksana dalam mengetahui yang harus dilakukan secara jelas; adanya penyampaian informasi kepada kelompok sasaran (target group) terkait tujuan dan sasaran kebijakan sehingga kesenjangan antara rencana dan pelaksanaan kebijakan dapat berkurang. Ketidakjelasan penyampaian informasi tentang tujuan dan sasaran suatu kebijakan kepada kelompok sasaran, memungkinkan terjadi gejolak dari kelompok sasaran. Kemampuan komunikasi diarahkan agar pelaksana kegiatan dapat bertukar pikiran satu sama lain dan menemukan titik kesepakatan yang saling menguntungkan sehingga dapat meningkatkan kinerja personal dalam bekerja dengan menemukan win-win solution pada setiap permasalahan. ${ }^{8}$

3. Sumberdaya.

Ketersediaan sumberdaya (manusia, materi, dan metoda) menjasalah satu penunjang dalam pelaksanaan kebijakan. Kecermatan, kejelasan, dan konsistensi menjadi hal yang diperlukan dalam pelaksanaan kebijakan, tetapi pelaksanaaan kebijakan akan cenderung tidak dapat dilaksanakan secara efektif jika para pelaksana kekurangan sumberdaya yang diperlukan. Kebijakan hanya akan menjadi dokumen yang tidak diwujudkan untuk menjawab permasalahan yang ada terkait memberikan pelayanan pada masyarakat tanpa dukungan sumberdaya. Dengan demikian, salah satu faktor penting dalam pelaksanaan kebijakan publik adalah aspek sumberdaya.

${ }^{8}$ Ibid., hal. 5 . 
Sumberdaya dalam pelaksanaan kebijakan publik diantaranya: staf yang memadai, informasi, pendanaan, wewenang, dan fasilitas pendukung lainnya. ${ }^{9}$

4. Disposisi atau sikap dari pelaksana.

Watak dan karakteristik yang dimiliki oleh pelaksana kebijakan, seperti komitmen, disiplin, kejujuran, kecerdasan, dan sifat demokratis merupakan pengertian dari disposisi. Pelaksana kebijakan yang memiliki disposisi yang baik, diduga kuat akan menjalankan kebijakan dengan baik, sebaliknya apabila pelaksana kebijakan yang memiliki sikap atau cara pandang yang berbeda dengan maksud dan arah dari kebijakan, maka proses pelaksanaan kebijakan tersebut dimungkinkan tidak akan efektif dan efisien.

Salah satu yang mempengaruhi kelancaran atau hambatan terhadap pelaksanaan kebijakan adalah disposisi atau sikap para pelaksana yaitu tergantung dari kesesuaian kompetensi dan sikap dari pelaksana. Karena itu, pentingnya dalam pemilihan dan penetapan personalia pelaksana kebijakan dimana perlu dipersyaratkan individu-individu yang memiliki kompetensi dan dedikasi yang tepat pada kebijakan yang telah ditetapkan. ${ }^{10}$

\section{HASIL DAN PEMBAHASAN}

Adapun tahap-tahap kebijakan publik atau sikulus Kebijakan Sekolah Ramah Anak di MTsN Sleman adalah sebagai berikut:

A. Tahap penyusunan agenda

Pada tahap ini, kebijakan Sekolah Ramah Anak telah dipilih dan diangkat menempati masalah pada agenda publik dengan berdasarkan latar belakang yang dianggap penting oleh para pejabat terkait diantaranya yaitu:

Dua hal besar yang melatar belakang lahirnya Sekolah Ramah Anak (SRA) yaitu untuk memenuhi hak anak sebagaimana tercantum dalam Konvensi

${ }^{9}$ Ibid., hal. 5.

${ }^{10}$ Ibid., hal. 6. 
Hak Anak yang telah di ratifikasi Indonesia pada Tahun 1990 sebagai amanat yang harus diselenggarakan Negara, juga adanya tuntutan dari Undang-Undang Nomor 23 Tahun 2003 tentang Perlindungan Anak dan Undang-Undang Nomor 35 Tahun 2014 tentang Perubahan atas Undang-Undang Nomor 23 Tahun 2003 tentang Perlindungan Anak yang jelas pada pasal 54 yang berbunyi : “(1) Anak di dalam dan di lingkungan satuan pendidikan wajib mendapatkan perlindungan dari tindak kekerasan fisik, psikis, kejahatan seksual, dan kejahatan lainnya yang dilakukan oleh pendidik, tenaga kependidikan, sesama peserta didik, dan/atau pihak lain”. Pada ayat dua dinyatakan sebagai berikut : “(2) Perlindungan sebagaimana dimaksud pada ayat (1) dilakukan oleh pendidik, tenaga kependidikan, aparat pemerintah, dan/atau masyarakat". ${ }^{11}$

Selain itu, latarbelakang adanya program Sekolah Ramah Anak lainnya yaitu juga karena dalam proses pendidikan, anak masih dijadikan sebagai obyek dan guru sebagai pihak yang selalu benar serta masih seringnya kejadian bullying yang terjadi di sekolah/madrasah. Merujuk pada data KPAI tahun 2014-2015 tentang Kasus Kekerasan (Kekerasan Fisik, Psikis, Seksual dan Penelantaran Terhadap Anak), sebanyak 10\% adalah dilakukan oleh guru. Pelecehan (bullying) serta bentuk-bentuk hukuman yang tidak mendidik kepada anak menjadi yang masih banyak ditemukan dengan rincian yaitu seperti mencubit sebanyak 504 kasus, membentak dengan suara keras sebanyak 357 kasus dan menjewer sebanyak 379 kasus. Selain itu, rawannya kekerasan pada anak juga terjadi karena $55 \%$ orang tua memberikan akses kepada anak terhadap kepemilikan handphone dan internet tetapi $63 \%$ orang tua menyatakan bahwa tidak melakukan pengawasan terhadap konten yang diakses oleh anak-anak. ${ }^{12}$

Adanya Program untuk mengembangkan Kota Layak Anak juga turut serta menjadi yang melatarbelakangi lahirnya kebijakan Sekolah Ramah Anak karena di dalam kebijakan Kota Layak Anak terdapat indikator penting terkait

11 Kementerian Pemberdayaan Perempuan dan Perlindungan Anak Republik Indonesia, Panduan Sekolah Ramah Anak, (KPPPA: Jakarta, 2015), hal. 9

12 Ibid., hal. 9. 
evaluasi pemenuhan $31 \mathrm{Hak}$ anak dimana salah satunya yaitu melalui adanya Sekolah Ramah Anak. ${ }^{13}$

B. Tahap formulasi kebijakan

Para pembuat kebijakan kemudian membahas untuk mencari pemecahan terbaik atas masalah yang telah masuk ke agenda kebijakan. Pada tahap ini, masing-masing aktor akan "bermain" untuk mengusulkan pemecahan masalah terbaik

Adapun aktor atau pihak-pihak yang terlibat atau berpartisipasi dalam penyusunan kebijakan Sekolah Ramah Anak diantaranya yaitu: Badan Perencanaan Pembangunan Nasional atau Bappenas, Kementerian Pendidikan dan Kebudayaan, Kementerian Agama, Kementerian Dalam Negeri, Kementerian Kesehatan, Kementerian Kehutanan dan Lingkungan Hidup, Kementerian Pekerjaan Umum dan Perumahan Rakyat, Badan Pengawas Obat dan Makanan, Badan Narkotika Nasional, Badan Penanggulangan Bencana dan Kementerian Pemberdayaan Perempuan dan Perlindungan Anak, serta Yayasan Kerlip. $^{14}$

Setelah masing-masing aktor mengusulkan pemecahan masalah terbaiknya, lahirlah empat paket kebijakan yaitu panduan Sekolah Ramah Anak, Peraturan Presiden tentang Gerakan Sekolah Ramah Anak, Modul Training of Trainer SRA, dan Materi untuk Modul Pelatihan Pendidikdan Tenaga Kependidikan yang akan diintegrasikan kedalam Modul Pelatihan Guru yang ada di Kementerian Pendidikan dan Kebudayaan untuk memperkuat Kebijakan Sekolah Ramah Anak (SRA) agar dapat terimplementasi di daerah dengan standar yang jelas. ${ }^{15}$

C. Tahap adopsi kebijakan

Setelah pada akhirnya kebijakan sekolah ramah anak ditetapkan sebagai satu alternatif kebijakan dengan dukungan mayoritas legislatif, konsensus antara

13 Ibid., hal. 10.

${ }^{14}$ Kementerian Pemberdayaan Perempuan dan Perlindungan Anak Republik Indonesia, Panduan Sekolah Ramah Anak, (KPPPA: Jakarta, 2015), hal. 5.

15 Ibid., hal. 2. 
direktur lembaga atau keputusan peradilan terkait, kemudian kebijakan tersebut dapat diadopsi atau diterapkan dengan memerlukan keterlibatan dan partisipasi semua pihak dalam mewujudkannya baik peserta didik, guru dan pihak sekolah lainnya. Dalam bimbingan para guru yang penuh perhatian dan bermotivasi tinggi, anak-anak yang belajar di sekolah ramah anak tumbuh sehat dan bahagia dengan didukung oleh keluarga dan masyarakat yang membantu seluruh anak baik perempuan maupun laki-laki termasuk anak yang memerlukan pendidikan dan fasilitas khusus (disabilitas) dalam lingkungan yang aman, bersih, sehat, hijau, inklusi dan nyaman.

D. Tahap implementasi kebijakan

Jika suatu program yang telah ditetapkan kemudian tidak diimplementaiskan, hal tersebut hanya akan menjadi catatan-catatan elite yang tidak ada artinya. Oleh karena itu, badan-badan administrasi maupun agen-agen pemerintah ditingkat bawah menjadi bagian yang mengimplementasikan keputusan program kebijakan yang telah dipilih sebagai alternatif pemecahan masalah. Salah satu pelaksana atau yang mengimplementasikan Kebijakan Sekolah Ramah Anak adalah MTsN 6 Sleman.

1. Tahap Implementasi Kebijakan Sekolah Ramah Anak di MTsN 6 Sleman

MTsN 6 Sleman mendapatkan label Sekolah Ramah Anak pada tahun 2017. Namun demikian, upaya penerapan untuk mewujudkan sekolah ramah anak sudah sejak lama terus berusaha dilakukan oleh semua pihak sekolah meski dengan standar yang berbeda-beda. Pada saat itu, belum ada standar yang pasti ditetapkan oleh peraturan tertentu. Akan tetapi, setelah Kementerian Pemberdayaan Perempuan dan Perlindungan Anak atau Badan PP (Perlindungan Perempuan) dan PA (Perlindungan Anak) bersama-sama dengan Gugus Tugas KLA (Kota Layak Anak) atau Tim Koordinasi SRA daerah Yogyakarta melakukan kegiatan sosialisasi tentang Pemenuhan Hak dan Perlindungan Anak dalam SRA kepada pihak sekolah, kemudian dilanjutkan dengan masing-masing satuan pendidikan melakukan penyusunan program SRA, sampai pada pelaksanaan penandatanganan komitmen bersama untuk mewujudkan SRA di Satuan Pendidikan yang melibatkan 
semua pihak terkait, sekolah menjadi memiliki arah perkembangan SRA dengan standar yang jelas sesuai yang ditetapkan dalam panduan SRA.

Program sekolah ramah anak merupakan salah satu upaya untuk mewujudkan kondisi nyaman, aman, bersih, sehat, peduli, dan berbudaya lingkungan hidup, yang mampu menjamin pemenuhan hak dan perlindungan anak dari kekerasan, diskriminasi, dan perlakuan salah lainnya selama anak berada di lingkungan sekolah yang mana menjadi rumah kedua bagi anak setelah rumahnya sendiri sehingga kasus yang terjadi di sekolah mulai dari kekerasan sampai keracunan makanan bahkan sampai pada kasus kematian karena kecelakaan di sekolah dapat dan harus dihindarkan.

2. Aspek-Aspek yang Mempengaruhi Implementasi Kebijakan Sekolah Ramah Anak di MTsN 6 Sleman

Dalam menganalisis implementasi Program Sekolah Ramah Anak di MTsN 6 Sleman, Peneliti mennggunakan teori Edwards III dimana terdapat 4 aspek yang memperngaruhi pelaksanaan suatu kebijakan yaitu sebagai berikut:

a. Kewenangan/ Struktur Birokrasi.

Ditinjau dari aspek struktur birokrasi, implementasi Program Sekolah Ramah Anak di MTsN 6 Sleman yaitu tidak adanya struktur organisasi dalam pelaksanan program sekolah ramah anak dan hanya disesuaikan dengan struktur organisasi sekolah sehingga koordinasi pihak sekolah mengenai Program Sekolah Ramah Anak kurang terstruktur. Hal tersebut karena terjadinya pemindahtugasan beberapa guru yang merupakan koordinator Sekolah Ramah Anak ke sekolah lain sehingga struktur organisasi Program SRA yang sudah terbentuk sebelumnya, dikembalikan kepada struktur organisasi sekolah.

b. Komunikasi.

Ditinjau dari aspek komunikasi, implementasi Program Sekolah Ramah Anak di MTsN 6 Sleman sudah cukup baik, terbukti dengan diadakannya sosialisasi dan pelatihan kepada guru serta sosialisasi kepada 
orang tua siswa dan pengarahan kepada peserta didik di MTsN 6 Sleman mengenai Program Sekolah Ramah Anak. Tidak hanya itu, terjalinnya koordiansi yang baik antara kepala sekolah terhadap guru maupun orang tua menjadi faktor yang mendukung keberhasilan dari penerapan Program Sekolah Ramah Anak di MTsN 6 Sleman.

c. Sumberdaya.

Ditinjau dari aspek sumberdaya, implementasi Program Sekolah Ramah Anak di MTsN 6 Sleman sudah cukup memadai baik sumber daya manusia maupun sumber daya sarana dan prasarana. Terbukti dengan pendidik dan tenaga kependidikan yang sudah terlatih hak-hak anak dimana dalam pelaksanaannya sudah menunjukkan prinsip-prinsip sekolah ramah anak diantaranya: menciptakan situasi dan kondisi nyaman, bahagia, penuh kasih sayang dan bebas dari perlakuan diskriminasi terhadap peserta didik baik di dalam maupun di luar kelas, juga tersedianya sarana prasarana yang cukup lengkap mendukung pelaksanaan program sekolah ramah anak, diantaranya yaitu: ruang kelas, perpustakaan, ruang bimbingan konseling, ruang komputer, mushola, kamar mandi, ruang UKS, perpustakaan, kantin, dll yang aman, nyaman, sehat, dan bersih.

d. Disposisi atau sikap dari pelaksana

Ditinjau dari aspek disposisi, implementasi Program Sekolah Ramah Anak di MTsN 6 Sleman yaitu terdapat sikap positif dan komitmen dari semua pihak sekolah untuk terus mengimplementasikan Program Sekolah Ramah Anak dengan penuh tanggung jawab. Diantaranya yaitu: memiliki komitmen tertulis dalam bentuk ikrar untuk mencegah kekerasan terhadap anak berbentuk pakta integritas yang dalam pembentukannya melibatkan semua pihak sekolah; memiliki komitmen untuk mewujudkan kawasan bebas rokok dan narkoba; pelaksanaan pembelajran yang adil yaitu tidak bias gender, inklusif dan nondiskiriminatif serta aman, nyaman, bersih, sehat dan menyenangkan; peserta didik diberikan kesempatan memilih kegiatan ekstrakurikuler 
sesuai dengan minatnya; sekolah memfasilitasi pengembangan potensi, minat dan bakat peserta didik dengan baik; peserta didik dilibatkan dalam menyusun kebijakan dan tata tertib sekolah; pemberian sanksi atau hukuman yang anti kekerasan baik fisik dan psikis kepada siswa, serta baik siswa dan seluruh pihak sekolah menciptakan hubungan yang positif dengan budaya senyum, salam, sapa, salim di lingkungan sekolah.

3. Model Pembelajaran Sekolah Ramah Anak di MTsN 6 Sleman

Dalam implementasinya, model pembelajaran Sekolah Ramah Anak yang digunakan MTsN 6 Sleman yaitu Child Friendly Teaching Model (CFTM) yang berbasis 3P yaitu Provisi, Proteksi, dan Partisipasi.

Pertama, model pembelajaran yang berbasis Provisi yaitu guru dalam proses pembelajaran di MTsN 6 Sleman sudah cukup memperhatikan apa yang dibutuhkan oleh peserta didik, seperti cara guru mengajar yang baik dan menyenangkan, memenuhi kebutuhan kesehatan dan kasih sayang anak di kelas yaitu dengan sudah tidak digunakannya kapur sebagai alat tulis tetapi digantikan dengan penggunaan spidol. Hal tersebut dengan pertimbangan bahwa debu dari butiran kapur dapat membahayakan kesehatan pernafasan anak. Selain itu penggunaan LCD di setiap kelas dalam pembelajaran juga membantu siswa untuk lebih mudah memahami pelajaran yang diajarkan.

Kedua, model pembelajaran yang berbasis proteksi yaitu guru di MTsN 6 Sleman sudah cukup memberikan perlindungan dan rasa aman kepada peserta didik dari bahaya, ancaman, diskriminasi, pelecehan, dll. Diantaranya yaitu: hukuman yang diberikan oleh guru kepada peseta didik ketika melakukan kesalahan atau pelanggaran didalam kelas tidak pernah berupa hukuman yang menyakitkan baik fisik maupun psikis anak, akan tetapi pemberian sanksi atau hukuman lebih kepada pembinaan, pemberian nasehat, kemudian barulah pemberian sanksi yang edukatif.

Ketiga, model pembelajaran yang berbasis partisipasi yaitu guru di MTsN 6 Sleman sudanak cukup memberikan kesempatan kepada peserta didik dalam hal kebebasan berekspresi maupun mengemuka kan pendapat di 
dalam kelas. Anak diberikan kesempatan untuk bertanya, menjawab atau berargumen terkait pelajaran yang dijelaskan. Suasana belajar yang diciptakan di kelas pun tidak tegang dan kaku karena guru menggunakan berbagai metode pembelajaran yang disesuaikan dengan konteks materi yang hendak disampaikan, termasuk penggunaan metode diskusi yang sering digunakan dalam menyampaikan materi pelajaran kepada siswa sehingga terbentuk siswa yang aktif dan bukan siswa banyak aktivitas di kelas.

4. Faktor Pendukung dan Penghambat serta Strategi Mengatasinya dalam Implementasi Kebijakan Sekolah Ramah Anak di MTsN 6 Sleman

Di dalam implementasi kebijakan sebuah program, tentunya akan selalu ada faktor pendukung dan faktor penghambat. Adapun faktor-faktor pendukung implementasi kebijakan sekolah ramah anak, diantaranya yaitu terdapat pada sikap positif dan komitmen dari semua pihak sekolah dan pihak lainnya terutama orang tua untuk terus mengimplementasikan Program Sekolah Ramah Anak dengan penuh tanggung jawab. Sikap guru ke siswa, begitupun sebaliknya menunjukkan sikap saling berkesinambungan menciptakan lingkungan yang nyaman sesuai prinsip sekolah ramah anak, dengan didukung fasilitas yang cukup memadai, guru terus berupaya memberikan pelayanan mengajar yang baik dan menyenangkan kepada peserta didik. Kemudian dukungan positif juga ditunjukkan dari pihak orang tua melalui adanya POT (Paguyuban Orang Tua) dimana setiap bulan diadakan pertemuan POT untuk mengetahui perkembangan anak di sekolah. Selain itu POT juga memiliki grub WA yang terhubung dengan pihak sekolah dimana memudahkan komunikasi sehingga terjalin kerjasama yang baik antara pihak sekolah dan orang tua.

Sedangkan, faktor penghambat dalam mplementasi Program Sekolah Ramah Anak di MTsN 6 Sleman diantaranya yaitu terletak pada sumber daya finansial dan sarana prasarana, dimana dari aspek sumber daya finansial hanya berasal dari dana BOS yang fokus pengalokasiannya tidak hanya pada program sekolah ramah anak, namun ada pembagian alokasi dana untuk dianggarkan ke aspek yang lainnya juga. Sehingga jika hanya mengandalkan 
dana BOS tidaklah cukup. Oleh karena itu, dalam hal ini adanya anggaran lain dari komite sekolah cukup membantu dalam menutupi kekurangan finansial dalam pelaksanaan program sekolah ramah anak, terutama untuk memfasilitasi pengembangan minat dan bakat peserta didik. Selama ini respon orang tua terkait adanya dana POT pun cukup positif, contohnya seperti ketika ada lomba menghias kelas dalam rangka memberikan kesempatan kepada peserta didik dalam mengatur ruang kelasnya agar dapat senyaman mungkin menikmati proses pembelajaran di sekolah, dalam hal ini orang tua sangat mendukung baik finansial maupun moral yaitu dengan memberikan sumbangan dana dan mendampingi selama pelaksanaan menghias kelas berlangsung. Selain itu, melalui dana POT yang dikelola oleh komite sekolah, juga cukup membantu memenuhi kebutuhan anak dalam mengembangkan bakat dan minatnya. Contohnya yaitu untuk pogram kelas khusus (kelas bahasa, enterpeneur, dan kelas KIR) dan ekstrakurikuler (futsal, basket, tapak suci, dll) dimana kebanyakan gurunya didatangkan dari luar, sumber dananya juga merupakan dukungan dari POT.

Kemudian dari aspek sarana dan prasarana di MTsN 6 Sleman sudah cukup mendukung implementasi sekolah ramah anak, hanya saja belum maksimal pada sarana prasarana yang ramah untuk anak berkebutuhan khusus (disabilitas). Hal ini karena selama ini belum pernah ada siswa disabilitas yang mendaftar di sekolah tersebut. Namun demikian, memang dibutuhkn dana yang tidak sedikit untuk memenuhi fasilitas yang ramah bagi anak berkebutuhan khusus. Sedangkan sumber finansial untuk pengimplementasi Program Sekolah Ramah Anak hanya dianggarkan dari dana BOS.

Meskipun di MTsN 6 Sleman tidak ada anak berkebutuhan khusus, tapi bukan tidak mungkin nantinya akan ada anak berkebutuhan khusus yang mendaftar di sekolah tersebut. Apabila anak berkebutuhan khusus memenuhi kriteria penerimaan siswa di MTsN 6 Sleman, sekolah tetap berkomitmen untuk menerima anak tersebut karena MTsN 6 Sleman berupaya memberikan perlindungan kepada anak dari diskriminasi. 
E. Tahap monitoring dan evaluasi kebijakan

Untuk melihat sejauh mana kebijakan yang dibuat telah mampu memecahkan masalah, diperlukan penilaian atau evaluasi terkait kebijakan yang telah dijalankan. Oleh karena itu, ditentukanlah ukuran-ukuran atau kriteriakriteria yang menjadi dasar untuk menilai apakah kebijakan publik telah meraih dampak yang diinginkan.

Monitoring implementasi program sekolah ramah di MTsN 6 Sleman dilakukan setiap sebulan sekali oleh Tim Pengembangan SRA dengan mengadakan rapat pertemuan yang melibatkan semua pihak termasuk perwakilan siswa dari anggota OSIS. Kemudian, evaluasi pengembangan sekolah ramah anak dilaksanakan oleh Tim SRA yang melibatkan gugus tugas KLA dan Dinas atau lembaga lainnya serta tidak menutup kemungkinan pemantauan dilakukan oleh KPP dan PA yang disesuaikan dengan kebutuhan dengan mengacu kepada instrument yang dibuat oleh KPPPA. Hasil evaluasi menjadi masukkan untuk setiap Satuan Kerja Perangkat Daerah, pengelola sekolah, dan semua pihak yang terlibat dalam menindaklajuti perbaikan pengembangan sekolah ramah anak.

\section{KESIMPULAN}

Berdasarkan hasil penelitian tentang analisis konsep dasar siklus kebijakan sekolah ramah anak di MTsN 6 Sleman dapat diambil kesimpulan diantaranya yaitu: setelah melalui tahapan penyusunan agenda, formulasi kebijakan, dan adopsi kebijakan, lahirlah empat paket kebijakan untuk memperkuat Kebijakan Sekolah Ramah Anak (SRA) agar dapat terimplementasi di daerah, salah satunya yaitu di MTsN 6 Sleman dengan melibatkan partisipasi semua pihak.

Kemudian, tahap implementasi kebijakan sekolah ramah anak di MTsN 6 Sleman yaitu: (1) Struktur Birokrasi dalam mengimplementasikan program sekolah amah anak di MTsN 6 Sleman disesuaikan dengan struktur organisasi sekolah; (2) Komunikasi melalui diadakannya sosialisasi mengenai program sekolah ramah anak kepada seluruh pihak terkait seperti guru, siswa dan orang tua; (3) Sumber daya manusia, sarana prasarana, dan finansial cukup mendukung dalam 
mengimplementasikan program sekolah ramah anak; (4) Disposisi melalui adanya sikap yang positif dan komitmen seluruh warga sekolah untuk terus mengimplementasikan program sekolah ramah anak di MTsN 6 Sleman; Model pembelajaran yang digunakan di MTsN 6 Sleman sudah cukup menerapkan prinsip sekolah ramah anak yaitu provisi, proteksi, dan partisipasi. Faktor pendukungnya yaitu sumberdaya manusia, sarana prasana, dan finansial sedangkan faktor penghambatnya adalah kurang maksimalnya sumberdaya sarana prasarana dan finansial dalam mewujudkan fasilitas yang ramah bagi anak berkebutuhan khusus.

Monitoring dan evaluasi implementasi program sekolah ramah di MTsN 6 Sleman dilakukan oleh Tim Pengembangan SRA yang melibatkan gugus tugas KLA dan Dinas atau lembaga lainnya serta tidak menutup kemungkinan pemantauan dilakukan oleh KPP dan PA yang disesuaikan dengan kebutuhan dengan mengacu kepada instrument yang dibuat oleh KPPPA.

\section{DAFTAR PUSTAKA}

Asisten Deputi Pemenuhan Hak Pendidikan Anak, Deputi Bidang Tumbuh Kembang Kementerian Pemberdayaan Perempuan dan Perlindungan Anak, Kebijakan Pengembangan Sekolah Ramah Anak, KPPA: Jakarta, 2014

Hasbullah, M, Kebijakan Pendidikan: Dalam Perspektif Teori, Aplikasi, dan Kondisi Objektif Pendidikan di Indonesia, Jakarta: Rajawali Pers, 2015

Kementerian Pemberdayaan Perempuan dan Perlindungan Anak Republik Indonesia, Panduan Sekolah Ramah Anak, KPPPA: Jakarta, 2015

Peraturan Menteri Negara Pemberdayaan Perempuan dan Perlindungan Anak Republik Indonesia Nomor 8 Tahun 2014 Tentang Kebijakan Sekolah Ramah Anak.

Ramadhani, Abdullah dan Muhammad Ali Ramadhani, "Konsep Umum Pelaksanaan Kebijakan Publik", Jurnal Publik, Vol. 11 No. 01, Januari 2017

Rusdiana, A, Kebijakan Pendidikan Dari Filosofi Ke Implementasi, Bandun: Pustaka Setia, 2015

Winarno, Budi, Kebijakan Publik: Teori, Proses, dan Studi kasus, Yogyakarta: CAPS Center of Academic Publishing Service, 2014

https://news.detik.com/berita/d-4532984/kpai-angka-kekerasan-pada-anak-januari april-2019-masih-tinggi, diakses pada tanggal 19 Novemver 2019, pukul 15.10 WIB. 